\title{
The Complement C3a and C3a Receptor Pathway in Kidney Diseases
}

\author{
Shuang Gao ${ }^{1,2,3,4}$, Zhao Cui ${ }^{1,2,3,4 *}$ and Ming-hui Zhao ${ }^{1,2,3,4,5}$ \\ ${ }^{1}$ Renal Division, Peking University First Hospital, Beijing, China, ${ }^{2}$ Institute of Nephrology, Peking University, Beijing, China, \\ ${ }^{3}$ Key Laboratory of Renal Disease, Ministry of Health of China, Beijing, China, ${ }^{4}$ Key Laboratory of CKD Prevention and \\ Treatment, Ministry of Education of China, Beijing, China, ${ }^{5}$ Peking-Tsinghua Center for Life Sciences, Beijing, China
}

OPEN ACCESS

Edited by:

Y. K. O. Teng

Leiden University Medical Center, Netherlands

Reviewed by: Alfred Hyoungiu Kim, Washington University School of Medicine in St. Louis, United States Jillian M. Richmond, University of Massachusetts Medical

School, United States

*Correspondence:

Zhao Cui

cuizhao@bjmu.edu.cn

Specialty section:

This article was submitted to Autoimmune and Autoinflammatory

Disorders,

a section of the journal

Frontiers in Immunology

Received: 26 April 2020

Accepted: 13 July 2020

Published: 18 August 2020

Citation:

Gao S, Cui Z and Zhao M (2020) The Complement С3a and С3a Receptor

Pathway in Kidney Diseases.

Front. Immunol. 11:1875

doi: 10.3389/fimmu.2020.01875
The pathogenesis of some kidney diseases is closely associated with complement activation, where the $\mathrm{C} 3 \mathrm{a} / \mathrm{C} 3 \mathrm{a}$ receptor $(\mathrm{C} 3 \mathrm{aR})$ might play a crucial role. $\mathrm{C} 3 \mathrm{a} / \mathrm{C} 3 \mathrm{aR}$ has dual roles and may exert anti-inflammatory or pro-inflammatory effects depending on different cell types and diseases. In the kidneys, C3aR is primarily expressed on the tubular epithelium and less in glomerular podocytes. C3aR expression is enhanced and the levels of $\mathrm{C} 3 \mathrm{a}$ in the plasma and urine are increased in kidney diseases of several types, and are associated with disease progression and severity. The C3a/C3aR pathway facilitates the progression of glomerular and tubulointerstitial diseases, while it has opposite effects on urinary tract infections. Clinical trials targeting $\mathrm{C} 3 \mathrm{a} / \mathrm{C} 3 \mathrm{aR}$ in kidney diseases are lacking. Here, we reviewed the studies on the C3a/C3aR pathway in kidney disease, with the aim of understanding in-depth its controversial roles and its potential therapeutic value.

Keywords: complement, $\mathrm{C} 3 \mathrm{a}, \mathrm{C} 3 \mathrm{a}$ receptor, kidney disease, inflammation

\section{INTRODUCTION}

Complement activation participates in the pathogenesis of a variety of diseases and induces tissue damage. The complement system is activated through three pathways (Figure 1). The classical pathway is initiated by the interaction of $\mathrm{C} 1$ with $\operatorname{IgG}$ or IgM antibodies, and then by cleavage of $\mathrm{C} 2$ and $\mathrm{C} 4$ to form the $\mathrm{C} 3$ convertase, C4b2a. In the lectin pathway, mannose-binding lectin (MBL) binds to the bacterial polysaccharide surface to form a complex, which also cleaves $\mathrm{C} 2$ and $\mathrm{C} 4$ to generate $\mathrm{C} 4 \mathrm{~b} 2 \mathrm{a}$. The alternative pathway involves spontaneous activation, $\mathrm{C} 3$ is cleaved to generate $\mathrm{C} 3 \mathrm{~b}$, then $\mathrm{C} 3 \mathrm{~b}$ constitutes another $\mathrm{C} 3$ convertase, $\mathrm{C} 3 \mathrm{bBb}$, with factor $\mathrm{B}(1)$.

The three pathways converge on $\mathrm{C} 3$ convertase, $\mathrm{C} 4 \mathrm{~b} 2 \mathrm{a}$ or $\mathrm{C} 3 \mathrm{bBb}$, which cleaves $\mathrm{C} 3$ and begins the common pathway. C3 is split between arginine (Arg) 77 and serine (Ser) 78 into two fragments, the smaller one as C3a and the larger one as C3b $(2,3)$. C3b is an opsonin that can lead to destruction of microbes by coating and decorating them. It also participates in the common pathway by forming the $\mathrm{C} 5$ convertase, $\mathrm{C} 4 \mathrm{~b} 2 \mathrm{aC} 3 \mathrm{~b}$ (in classical and lectin pathways) and $(\mathrm{C} 3 \mathrm{~b})_{2} \mathrm{Bb}$ (in alternative pathway). $\mathrm{C} 5$ convertase cleaves $\mathrm{C} 5$ into $\mathrm{C} 5 \mathrm{a}$ and $\mathrm{C} 5 \mathrm{~b}$. C5b binds to $\mathrm{C} 6$ and $\mathrm{C} 7$ to form a trimeric complex. Then, $\mathrm{C} 8$ and $\mathrm{C} 9$ bind to form the membrane attack complex (MAC). The lipophilic protein $\mathrm{C} 7$ makes the complex attached to the cell membrane by inserting into the lipid bilayer (2). 


\section{Classical pathway Lectin pathway Alternative pathway}

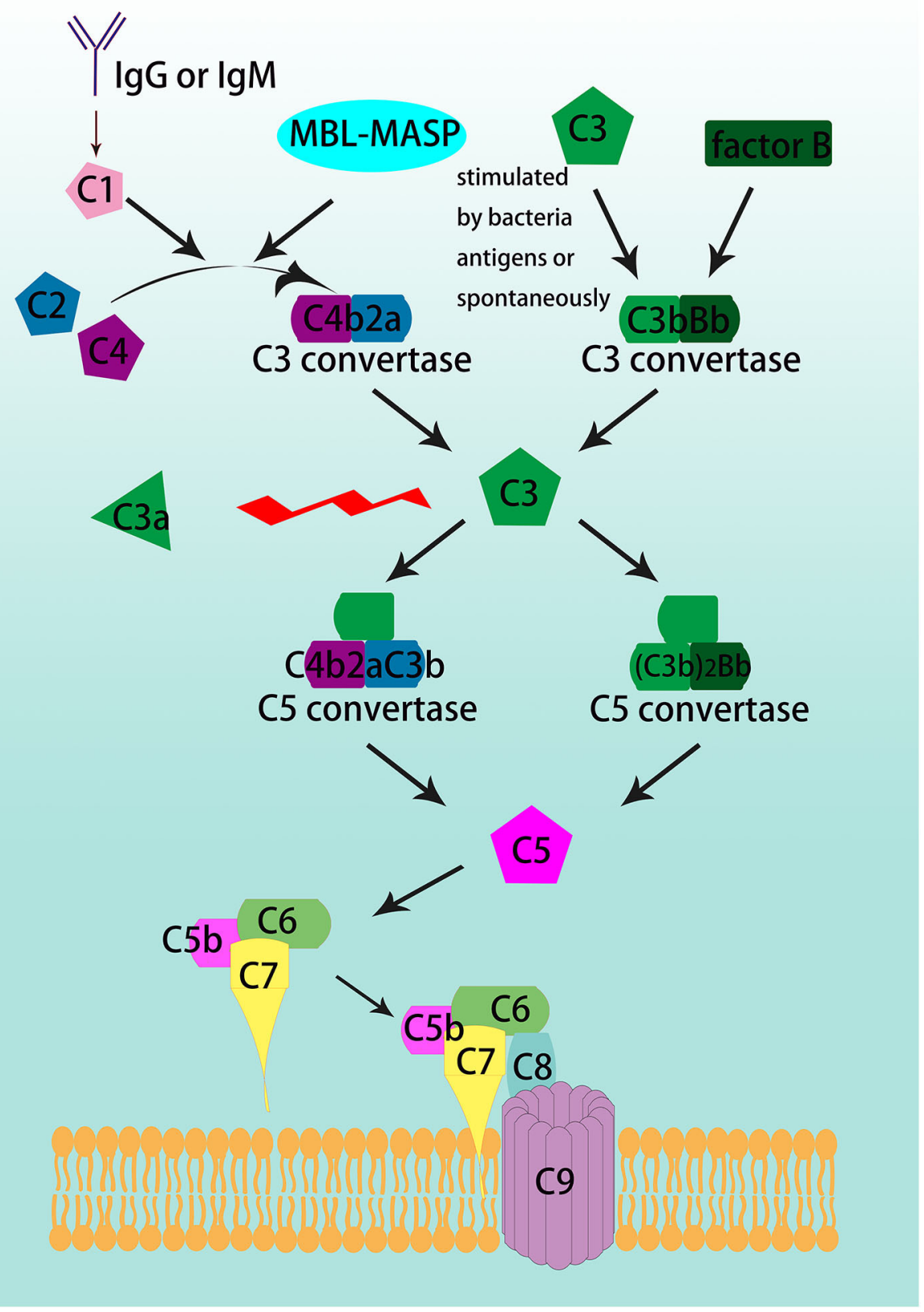

FIGURE 1 | Schematic overview of complement cascade. The complement system is activated through the classical, lectin, and alternative pathways, converge at the formation of C3 convertases. The classical pathway is activated by either lgG or lgM, the lectin pathway is triggered by the binding of mannose-binding lectin (MBL) to the pathogens' polysaccharide surface, and the alternative pathway begins with C3 spontaneous cleavage. C3 is the beginner and the core member of common pathway which is formed by the convergence of the three initiating pathways and activate C3, C5-C9 through sequence to form the terminal complement cascade, namely membrane attack complex (MAC).

$\mathrm{C} 3 \mathrm{a}$ is an anaphylatoxin that exerts various effects after binding to the $\mathrm{C} 3 \mathrm{a}$ receptor $(\mathrm{C} 3 \mathrm{aR})$. In kidneys, $\mathrm{C} 3 \mathrm{aR}$ is expressed at high levels on tubular epithelial cells (4). In glomeruli, the staining for $\mathrm{C} 3 \mathrm{aR}$ is restricted to glomerular epithelial cells (podocytes) and is much weaker than that in the tubule (4). There are controversies about the roles of $\mathrm{C} 3 \mathrm{a} / \mathrm{C} 3 \mathrm{aR}$ in kidney disease onset and tissue damage. In this review, we focused on the inflammatory effects after $\mathrm{C} 3 \mathrm{a}$ binding with $\mathrm{C} 3 \mathrm{aR}$ and its roles in the development of kidney diseases. 


\section{C3a and C3aR}

Human C3a is a small $9 \mathrm{kDa}$ peptide that comprises 77 amino acids and has four anti-parallel helical structures that are trapped by three disulfide bridges (5). The binding site of C3a to $\mathrm{C} 3 \mathrm{aR}$ includes the $\mathrm{C}$-terminal amino acids leucine-glycine-leucinealanine-Arg $(3,5)$. When C3a is cleaved to C3a-desArg, it loses the ability to bind to $\mathrm{C} 3 \mathrm{aR}$, but binds to the second receptor of C5a, named C5aR2 (5). The antibodies currently used to detect C3a can distinguish C3 from its cleavage product; however, they fail to discriminate $\mathrm{C} 3 \mathrm{a}$ from $\mathrm{C} 3 \mathrm{a}$-desArg, and may even detect C3a-desArg with higher sensitivity (5). Thus, it is necessary to develop antibodies that specifically recognize $\mathrm{C} 3 \mathrm{a}$. In healthy individuals, the plasma concentration of C3a is $119 \mathrm{ng} / \mathrm{ml}$, and is derived from the degradation of $\mathrm{C} 3$ in the alternative pathway (5). However, the C3a concentration varies widely in different studies, from 20 to $156 \mathrm{ng} / \mathrm{ml}$, due to the protocol and sample characteristics. The levels of $\mathrm{C} 3 \mathrm{a}$ are increased in the sera due to removal of proteases that hydrolyzes $\mathrm{C} 3 \mathrm{a}$ in the process of plasma clotting. Studies have reported that C3a levels in the circulation were elevated in pregnant women and may reach $182.5 \pm 150.0 \mathrm{ng} / \mathrm{ml}$ in the plasma in the first trimester $(5,6)$.

Human C3aR is a $55 \mathrm{kDa}$ protein comprising 482 amino acids and is a seven-transmembrane domain receptor that belongs to the G-protein coupled receptor family $(4,7-9)$. C3aR was first cloned in 1996 and was isolated from a cDNA expression library from U-937 cells (8). The human C3aR gene is located on chromosome 12p13.2-3 as a single copy. C3aR mRNA expression has been detected in several major organs such as the kidney (4), brain (10), lung (11), intestine (12), subcutaneous adipose tissue
(13), and other (9). There are mainly four post-translational modifications (14): C3aR is highly glycosylated; tyrosine sulfated $(9,15)$ and especially Tyr174 plays a critical role in high-affinity binding to C3a; phosphorylated and S-acylated (5). After binding to $\mathrm{C} 3 \mathrm{a}, \mathrm{C} 3 \mathrm{aR}$ is activated and triggers intracellular signaling. The principle signaling pathway is mediated by the pertussis toxin (PT)-sensitive $\mathrm{G}$ protein $\mathrm{G} \alpha_{i}$ in immune cells (16) and the PTinsensitive $G \alpha 12 / 13$ that leads to the activation of the ERK1/2 pathway and cytoskeletal changes (17). C3aR activation also causes an increase in intracellular $\mathrm{Ca}^{2+}$, while $\mathrm{C} 5 \mathrm{aR}$ activation has a stronger effect on promoting $\mathrm{Ca}^{2+}$ elevation (5). Another essential mediator is arrestin that can terminate the influence of $\mathrm{C} 3 \mathrm{aR}$ to $\mathrm{Ca}^{2+}$. A C3aR mutant failed to bind to $\beta$-arrestin 2 . Thus, in mast cells, $\mathrm{C} 3 \mathrm{aR}$ desensitization and internalization were inhibited by silencing $\beta$-arrestin 2 , which leads to a prolonged release of $\mathrm{Ca}^{2+}$ (18).

\section{The Function of $\mathrm{C} 3 \mathrm{a} / \mathrm{C}_{3} \mathrm{aR}$ in the Immune System}

$\mathrm{C} 3 \mathrm{a}$ is a critical chemotactic mediator in the immune system, and $\mathrm{C} 3 \mathrm{a} / \mathrm{C} 3 \mathrm{aR}$ pathway has a dual, anti-inflammatory and proinflammatory roles in different cells and diseases [Figure 2; (3)]. In general, $\mathrm{C} 3 \mathrm{a} / \mathrm{C} 3 \mathrm{aR}$ participates in the response of the immune system in three ways, acting on resident innate immune cells to up-regulate or down-regulate different cytokines, activate dendritic cells (DCs), and regulate $\mathrm{T}$ cell signaling between lymphocytes and antigen presenting cells (APCs) (19).

C3a acts anti-inflammatory effects in pathogens, i.e., bacteria/fungi, neutrophils in the bone marrow reservoir, and

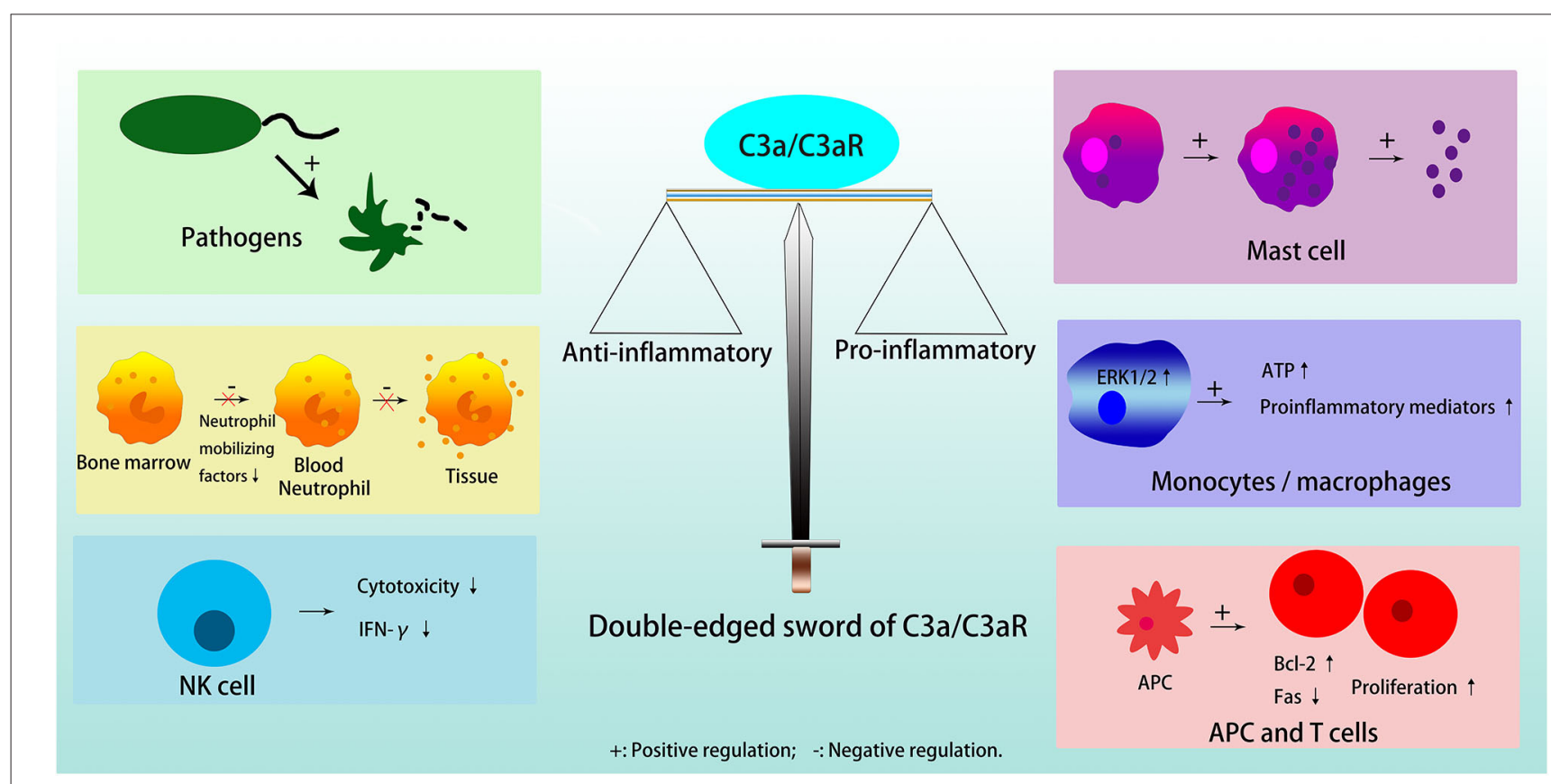

FIGURE 2 | Double edged sword of $\mathrm{C} 3 \mathrm{a} / \mathrm{C} 3 \mathrm{aR}$. C3a/C3aR plays anti-inflammatory effects in inducing pathogens elimination, inhibiting neutrophil migration from bone marrow and degranulation in tissue, and reducing cytotoxicity and expression of IFN- $\gamma$ in NK cell. C3a/C3aR plays pro-inflammatory effects in inducing mast cells to generate and secrete small granule spherical particles, upregulating the expression of proinflammatory mediators by activating ERK1/2 and releasing extracellular ATP in monocytes or macrophages, and promoting T cell proliferation and differentiation directly or indirectly through APC. 
natural killer (NK) cells. Furthermore, although there is a high expression of functional $\mathrm{C} 3 \mathrm{aR}$ on the neutrophil cell membrane, C3a does not stimulate neutrophil degranulation to activate inflammatory response (3). C3a can also inhibit the migration of neutrophils from the bone marrow into the circulation by directly inhibiting neutrophil mobilizing factors, for example, G-CSF $(3,18)$. In NK cells, C3a is a negative regulator because it is able to not only inhibit NK cell cytotoxicity in vivo, but also to down-regulate the expression of IFN- $\gamma(20)$.

C3a exerts pro-inflammatory functions in mast cells, macrophages/monocytes, T cells, and APC. Mast cells participate in allergic reactions, in which anaphylatoxin C3a induces them to produce and secrete small granule spherical particles, in a process named IgE-independent degranulation, through a rapid rise of intracellular calcium levels $(21,22)$. In monocytes or macrophages, $\mathrm{C} 3 \mathrm{a}$ induces the release of proinflammatory mediators after binding to C3aR, activation of ERK1/2, and release of extracellular ATP, which in turn induces P2X7 that cooperates with NF- $\kappa \mathrm{B}$ and enhances the production of IL-1 $\beta$ (23). When the activity of monocytes prevails over neutrophils, C3a plays a catalytic role in inflammation in general (3). In $\mathrm{T}$ cells, $\mathrm{C} 3 \mathrm{a} / \mathrm{C} 3 \mathrm{aR}$ activates phosphoinositide-3-kinase- $\gamma$ and induces phosphorylation of $\mathrm{AKT}$, while, it up-regulates the antiapoptotic protein $\mathrm{Bcl}-2$ and down-regulates the proapoptotic molecule Fas, to decrease $\mathrm{T}$ cell apoptosis and enhance their proliferation (24). In addition, $\mathrm{C} 3 \mathrm{a} / \mathrm{C} 3 \mathrm{aR}$ can promote $\mathrm{T}$ cell proliferation through its effect on APC (23). The absence of $\mathrm{C} 3, \mathrm{C} 3 \mathrm{a}$ or $\mathrm{C} 3 \mathrm{aR}$ on $\mathrm{APC}$ results in a reduction in $\mathrm{MHC}$ II expression, which limits $\mathrm{T}$ cell proliferation and differentiation by insufficient antigen presentation $(25,26)$. C3aR blockade or deficiency results in decreased secretion of inflammatory factors, such as IL-2 and IFN- $\gamma$ in T cells, and IL-1, IL-12, and IL-23 in APC (26).

In the studies of $\mathrm{C} 3 \mathrm{a}$ and $\mathrm{C} 3 \mathrm{aR}$, the $\mathrm{C} 3 \mathrm{aR}$ agonists and antagonists play pivotal roles. The peptide ligand WWGKKYRASKLGL, also called "super agonist," is the most effective C3aR agonist, 15-fold more potent than C3a. There are several new potent and selective agonists validated by the calcium release assay, that is, FLPLAR 26/24 and FWTLAR $54 / 55$. The most common and effective C3aR antagonist SB290157 is a trifluoroacetate salt, with an effective IC $_{50}$ of 27.7, 7.0 , and $12.5 \mathrm{nM}$ in human, mouse, and guinea pig RBL-2H3 cells, respectively (27). Nevertheless, SB290157 treatment had off-target activity resulting in rapid neutropenia and transient hypertension (28). There are even reports suggesting that SB290157 functions as an agonist. C3a binds to C3aR to induce calcium mobilization, a marker of C3aR activation, whereas SB290157 also induced calcium mobilization in a dose-dependent manner (28). SB290157 showed antagonist effects on cells with low levels of C3aR expression, while it acted as an agonist on cells with high levels of C3aR (29).

$\mathrm{C} 3 \mathrm{aR}$ knockout animals have been employed in numerous experiments, and questions arise regarding the choice of complete knockout or conditional knockout. In complete knockout animals, both local organs studied and circulating immune cells lack C3aR expression. Considering the different functions of $\mathrm{C} 3 \mathrm{aR}$ in different cells, its role in circulating cells might interfere with the effects on local organs. The conditional knockout animals can restrict $\mathrm{C} 3 \mathrm{aR}$ deficiency in specific organs, but the circulating immune cells that participate in the pathogenesis still possess normal expression of C3aR, which may weaken the effects. Thus, cautious interpretations should be given when there is a difference between the results from knockout animals and those with the C3aR antagonist.

$\mathrm{C} 3 \mathrm{a} / \mathrm{C} 3 \mathrm{aR}$ participates in the pathogenesis of various diseases. In Alzheimer's disease, the $\mathrm{C} 3 \mathrm{a} / \mathrm{C} 3 \mathrm{aR}$ pathway mediated microtubule-associated protein tau modulation by targeting STAT3, and the expression of $\mathrm{C} 3 \mathrm{aR}$ was negatively correlated with cognitive function and positively correlated with Braak stages (10). In asthma, C3a/C3aR promoted smooth muscle contraction, mucus secretion, and recruitment of inflammatory cells. Deficiency of $\mathrm{C} 3 \mathrm{aR}$ was protective to the lungs in a murine model of allergic airway disease $(30,31)$. In coronary artery disease, the expression of $\mathrm{C} 3 \mathrm{aR}$ was positively correlated with activated glycoprotein IIb/IIIa in platelets, and the incidence of stroke and myocardial infarction was reduced in $\mathrm{C}_{3} \mathrm{aR}^{-/-}$mice (32). C3a/C3aR played a protective role in intestinal ischemia-reperfusion (IR) injury by inhibiting neutrophil mobilization (33).

\section{C3a/C3aR in Kidney Diseases}

$\mathrm{C} 3 \mathrm{a} / \mathrm{C} 3 \mathrm{aR}$ plays crucial roles in various kidney diseases (Figure 3).

\section{Primary Glomerular Diseases \\ IgA nephropathy (IgAN)}

IgAN is characterized by mesangial IgA and C3 deposition, and C3a/C3aR contributes to its pathogenesis. In 1992, Abou-Ragheb et al. found a positive correlation between plasma C3a levels and plasma creatinine levels in patients with IgAN, and suggested the measurement of plasma anaphylatoxins as a possible indicator of disease activity and prognosis (34). However, Janssen et al. found that the C3a levels could not predict renal prognosis or reflect the status of neoantigens that develop after $\mathrm{C} 3$ activation, which is an indicator of disease activity and outcome (35). In 2014, Liu et al. observed elevated staining of C3aR and C3a in glomeruli, and high levels of $\mathrm{C} 3 \mathrm{a}$ in the sera and urine from IgAN patients (36). Both urinary C3a levels and glomerular $\mathrm{C} 3 \mathrm{aR}$ and $\mathrm{C} 3 \mathrm{a}$ staining correlated positively with proteinuria, serum creatinine levels, and histopathological injuries (30). In 2015, Zhu et al. found associations of variants of genes encoding complement factor $\mathrm{H}(\mathrm{CFH}), \mathrm{CFH}$-related protein 3 (CFHR3), $\mathrm{CFH}$-related protein 1 (CFHR1) with high levels of circulating C3 and low-levels of serum C3a in IgAN patients. CFHR1 protein is a competitive antagonist of $\mathrm{CFH}$; therefore, higher levels of $\mathrm{CFH}$ inhibit complement activation, leading to the inhibition of C3 cleavage to C3a. Thus, in patients with low CFH, CFHR1, or CFHR3, there is excess cleavage of $\mathrm{C} 3$ and a buildup of C3a in the plasma (37). In 2016, a study of a cohort of patients with IgAN revealed that plasmapheresis is effective in reducing urinary $\mathrm{C} 3 \mathrm{a}$ levels and the probability of dialysis-dependence (38). In 2017, Zhang et al. showed that C3aR knockout mice had lower levels of proteinuria and reduced IgA and C3 deposition in the kidney as well as reduced histological injury when IgAN was induced by 


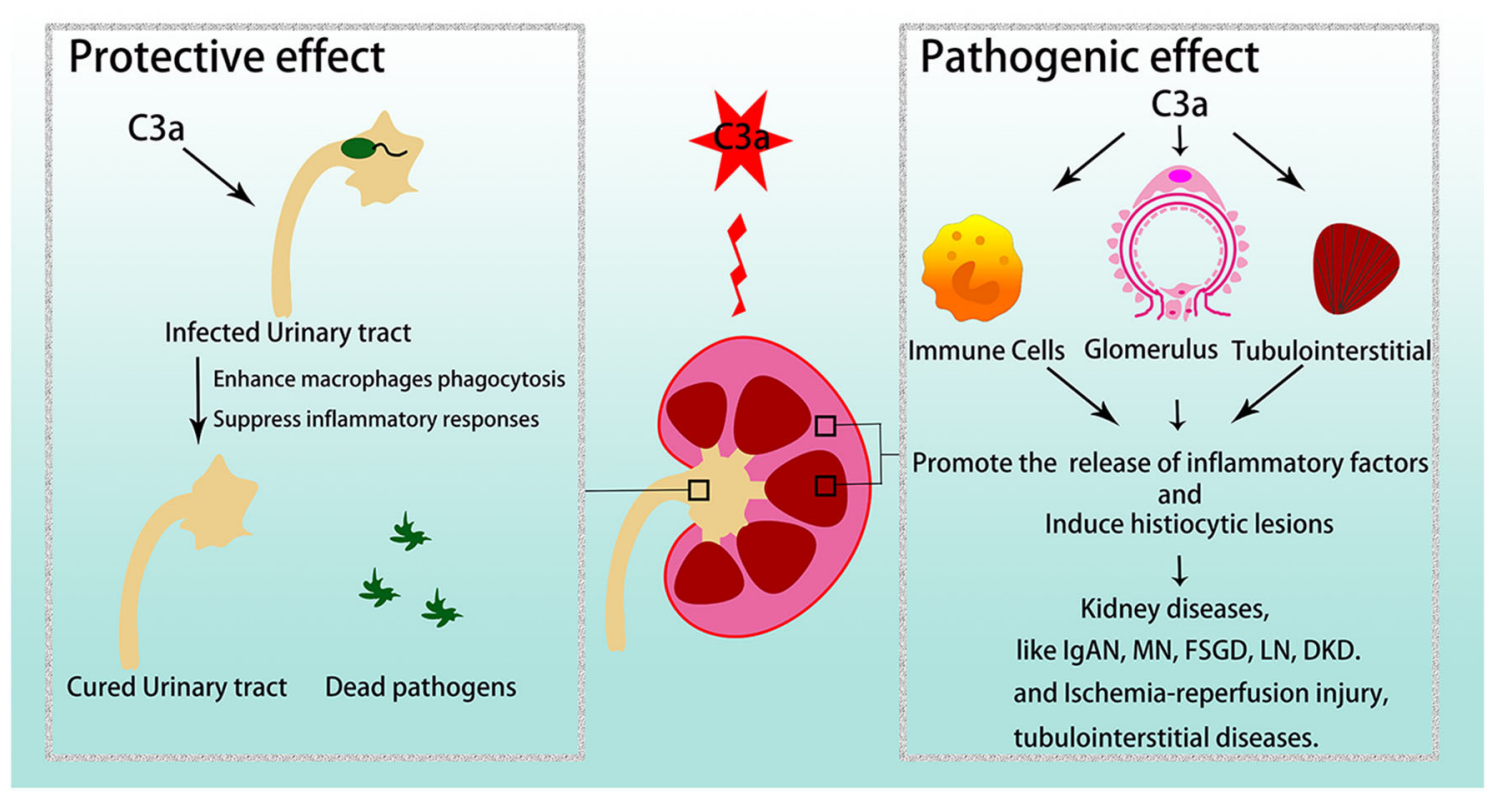

FIGURE 3 | C3a/C3aR in kidney diseases. C3a/C3aR is related to disease development and severity in various glomerular diseases and tubulointerstitial injuries. However, in urinary tract infections, C3a/C3aR acts protective effect. IgAN, IgA nephropathy; MN, membranous nephropathy; FSGS, focal segmental glomerulosclerosis; LN, lupus nephritis; DKD, diabetic kidney disease.

Sendai virus. They also detected a decrease in TNF- $\alpha$, TGF- $\beta$, IL$1 \beta$, IL-6, and monocyte chemoattractant protein-1 (MCP-1) in mouse kidneys (39). In 2019, Zhang et al. found that plasma C3a in patients with IgAN was positively correlated with plasma and mesangial galactose-deficient IgA1 molecules (Gd-IgA1) $(38,40)$.

These studies suggest a direct role of $\mathrm{C} 3 \mathrm{a} / \mathrm{C} 3 \mathrm{aR}$ in IgAN, although it is unclear whether its involvement is at the level of the kidney. A conditional knockout mouse, where $\mathrm{C} 3 \mathrm{aR}$ is deleted from the kidney, will be a useful tool to elucidate this.

\section{Membranous nephropathy (MN)}

Primary MN is currently identified as an autoimmune disorder of M-type phospholipase A2 receptor (PLA2R), which is expressed on podocyte membrane. Cross-sectional studies have found that C3a levels were remarkably high in the plasma and urine of MN patients, and they were even higher in the circulation of patients with positive total and IgG4 anti-PLA2R antibodies than those without the antibody. Patients who achieved complete remission had lower levels of serum C3a $(41,42)$. The deposition of IgG4 anti-PLA2R is a reliable predictor of $\mathrm{MN}$ that activates the complement cascade by binding to MASP-1/2/MBL complex (42). In hepatitis B virus-associated $\mathrm{MN}$, the significant reduction in plasma C3a levels was also related to remission during treatment (43).

We can speculate that $\mathrm{C} 3 \mathrm{a} / \mathrm{C} 3 \mathrm{aR}$ is involved in $\mathrm{MN}$ pathogenesis. Previous studies have only shown that circulating C3a levels increase and much work is needed to confirm the role of the $\mathrm{C} 3 \mathrm{a} / \mathrm{C} 3 \mathrm{aR}$ pathway. For example, we can further investigate $\mathrm{C} 3 \mathrm{aR}$ expression in podocytes, and can clarify the pathogenic role of $\mathrm{C} 3 \mathrm{a} / \mathrm{C} 3 \mathrm{aR}$ by inducing disease in $\mathrm{C} 3 \mathrm{a} / \mathrm{C} 3 \mathrm{aR}$ deficient animals or by blocking C3aR.

\section{Focal segmental glomerulosclerosis (FSGS)}

FSGS is caused by the loss or injury of podocytes. In 2016, Morigi et al. found that $\mathrm{C} 3 \mathrm{a} / \mathrm{C} 3 \mathrm{aR}$ participated in podocyte depletion and glomerulosclerosis. In FSGS patients with progressive proteinuria, protein-overload mice and in vitro podocyte culture, $\mathrm{C} 3 \mathrm{a} / \mathrm{C} 3 \mathrm{aR}$ caused podocyte damage by activating glial cell linederived neurotrophic factor (GDNF)/c-Ret (the receptor of GDNF) pathway, which is a critical adaptive response when podocytes are exposed to toxic injury. $\mathrm{C} 3 \mathrm{a} / \mathrm{C} 3 \mathrm{aR}$ also induced parietal epithelial cells to up-regulate CXCR4, which resulted in parietal epithelial cell proliferation and migration, and glomerulosclerosis (44). In adriamycin (ADR)-treated mice, Liu et al. found that $\mathrm{C} 3 \mathrm{aR}$ expression was increased in the kidneys. Furthermore, it has been found that resveratrol suppressed inflammatory response, glomerulosclerosis, and renal interstitial fibrosis through down-regulation of the C3aR/C5aR-Sphk1 pathway (33).

$\mathrm{C} 3 \mathrm{a} / \mathrm{C} 3 \mathrm{aR}$ also plays a role in tubulointerstitial fibrosis in FSGS. In 2018, Han et al. detected low-levels of expression of versican in $\mathrm{C}_{3} \mathrm{aR}^{-/-} \mathrm{ADR}$ mice. They suggested that $\mathrm{C} 3 \mathrm{a}$ promoted the transcription of versican. The $\beta$-catenin/TCF transcription factor complex was indispensable for the expression of versican. C3a induced the phosphorylation of AKT, which promotes $\beta$-catenin/T-cell factor (TCF) expression by inhibiting GSK-3 $\beta$ to directly phosphorylate $\beta$-catenin and indirectly stabilize it (45). They treated cultured tubular cells with sera from FSGS patients, which contained high levels of C3a and found 
that the expression of long non-coding RNA LOC105375913 was increased in a time- and dose-dependent manner, which resulted in the up-regulations of collagen I and fibronectin levels in tubular cells. This expression could be inhibited by a C3aR blocker (46).

Previous studies have shown that $\mathrm{C} 3 \mathrm{a} / \mathrm{C} 3 \mathrm{aR}$ participates in the pathogenesis of FSGS by regulating various signaling pathways both in glomeruli and tubules, and mentioned the protective function of the C3aR blocker. Furthermore, C3a/C3aR targeted therapy may be applied to FSGS patients.

\section{Secondary Glomerular Diseases Lupus nephritis (LN)}

LN is mediated by the deposition of immune complexes and complement activation products in the kidney tissue. Studies have shown that both $\mathrm{C} 3 \mathrm{a}$ and $\mathrm{C} 3 \mathrm{aR}$ are increased in patients with LN and related to disease severity and activity. In 2007, Mizuno et al. found that C3aR staining was positive in $42.9 \%$ of all LN kidney specimens and in $81.3 \%$ of sections classified as WHO IV LN. The intensity of C3aR staining was positively correlated with LN histological activity score (14). In 2017, Song et al. found that the plasma levels of C3a were elevated, especially in patients with active LN, while they were much lower in patients in remission and in SLE patients without clinical renal involvement (47). Animal experiments have validated the pathogenic effects of C3a/C3aR. As early as in 2005, Bao showed that in the kidneys of MRL/lpr mice, the expression of C3aR was significantly elevated. $\mathrm{C} 3 \mathrm{aR}$ antagonist treatment could reduce the expression of IL-1 $\beta$ and RANTES in the kidney, relieve pathological injuries, and prolong survival (48). However, in 2008, Wenderfer found a protective effect of C3aR in the early stage of $\mathrm{LN}$. In $\mathrm{C}_{3} \mathrm{aR}^{-/-} \mathrm{MRL} / \mathrm{lpr}$ mice at 8 weeks, various pathogenic chemokine receptors were found to be increased, except for MCP-1, and the mice showed an earlier onset of renal injury compared to the controls. However, C3aR expression in glomeruli had no effect on long-term prognosis (49).

Data show high levels of $\mathrm{C} 3 \mathrm{a}$ and $\mathrm{C} 3 \mathrm{aR}$ expression in $\mathrm{LN}$, but the direct role of $\mathrm{C} 3 \mathrm{a} / \mathrm{C} 3 \mathrm{aR}$ in the kidney remains to be elucidated. The immune system is over-activated in $\mathrm{LN}$, which reminds us of the role of $\mathrm{C} 3 \mathrm{a} / \mathrm{C} 3 \mathrm{aR}$ in the immune system mentioned above.

\section{Diabetic kidney disease (DKD)}

In patients with $\mathrm{DKD}, \mathrm{C} 3 \mathrm{a} / \mathrm{C} 3 \mathrm{aR}$ is remarkably activated and is involved in its pathogenesis. Both the levels of C3a in the plasma and urine were significantly elevated in DKD patients compared to diabetic patients without kidney injury $(50,51)$. Urinary $\mathrm{C} 3 \mathrm{a}$ was positively correlated with urinary protein as well as with the estimated glomerular filtration rate (eGFR). C3a was also correlated with glomerular lesion classification of DKD and the progression of disease $(50,52)$. C3aR expression was enhanced in early and advanced DKD (53). Li et al. have reported that $\mathrm{C} 3 \mathrm{aR}$ antagonist treatment could alleviate kidney damage in $\mathrm{DKD}$ rats induced by a high-fat diet and streptozotocin by inhibiting Wnt $/ \beta$-catenin, TGF- $\beta /$ smad 3 signaling pathways, $\mathrm{IKB} \alpha$ phosphorylation, and IL- 6 release, to reduce inflammation and fibrosis in glomerular endothelial cells $(53,54)$. Li et al. have also reported that $\mathrm{C} 3 \mathrm{aR}$-deficiency reduced kidney damage in diabetic rats. The possible mechanism was that the absence of C3aR suppressed T-cell activation by inhibiting the release of cytokines such as IL-4, IL-23, and IL-27 from macrophages (55).

The above studies have clearly demonstrated the pathogenic role of $\mathrm{C} 3 \mathrm{a}$ in $\mathrm{DKD}$ and suggested its mechanism. The next research direction is to use $\mathrm{C} 3 \mathrm{aR}$ as a therapeutic target to treat DKD.

\section{Tubulointerstitial Diseases Ischemia-reperfusion (IR) injury}

IR injury results in acute tubular necrosis, during which oxygen and nutrients needed to maintain normal metabolism are deprived, where the cells die through necrosis and release abundant endogenous ligands. After restoration of perfusion, endogenous ligands activate innate immune responses by stimulating inflammatory cell recruitment and activation $(56,57)$. In both tubular epithelial cells and infiltrating neutrophils, monocytes, and macrophages, $\mathrm{C} 3 \mathrm{a} / \mathrm{C} 3 \mathrm{aR}$ stimulated the production of cytokines and chemokines, such as TNF- $\alpha$, IFN- $\gamma$, MIP-1, MCP-1, IL-1 $\beta$, IL-6, IL-8, and IL-17, which are thought to be involved in IR kidney injury (56-58). C3a/C3aR also promoted the expression of KIM-1, which is a functional and specific marker for acute tubular necrosis $(56,57)$. Simone et al. have demonstrated that $\mathrm{C} 3 \mathrm{a}$ participated in IR injury by enhancing NADPH oxidase activity and promoting $\alpha$-SMA protein expression (59). Curci et al. have reported that IR injury promoted the process of $\mathrm{C} 3 \mathrm{a}$-induced epithelial to mesenchymal transition (EMT), which leads to fibrosis through the AKT pathway (60).

The C3a/C3aR pathway promotes ischemia-reperfusion injury through an excess of cytokines and oxidative stress. However, there are few reports on the changes in $\mathrm{C} 3 \mathrm{a} / \mathrm{C} 3 \mathrm{aR}$ expression. We need to examine whether the expression of $\mathrm{C} 3$ is abnormal during the injury. In addition, the direct effect of $\mathrm{C} 3 \mathrm{a} / \mathrm{C} 3 \mathrm{aR}$ in the kidney remains unresolved and requires further investigation.

\section{Chronic tubulointerstitial diseases}

Chronic tubulointerstitial inflammation and fibrosis occur in most chronic kidney diseases. Studies have shown that $\mathrm{C} 3 \mathrm{a} / \mathrm{C} 3 \mathrm{aR}$ can induce tubulointerstitial inflammation and fibrosis by mediating EMT in proximal tubular epithelial cells through the TGF- $\beta 1 /$ CTGF signaling pathway $(61,62)$. The C3aR antagonist effectively inhibited EMT induced by $\mathrm{C} 3 \mathrm{a}$, and ameliorated the pathology of ADR mice and preserved renal function and limited interstitial fibrosis (62). Bao et al. have induced complement activation by transplanting $\mathrm{Crry}^{-/-} \mathrm{C} 3^{-/-}$kidney to $\mathrm{C} 3 \mathrm{aR}^{-/-}$ host, where circulating $\mathrm{C} 3$ from the host acted on donor kidneys deficient in Crry (a membrane protein that inhibits C3 convertase, equivalent to human CD55) to induce complement activation. The results showed that deficiency in $\mathrm{C} 3 \mathrm{aR}$ reduced the kidney tubulointerstitial inflammation and fibrosis (63). C3a could induce T-cells to release IL-17A by ERK, STAT3/5, and NF- $\kappa$ B resulting in an inflammatory response and fibrosis (64).

Although studies have shown the pathogenic effect of $\mathrm{C} 3 \mathrm{a} / \mathrm{C} 3 \mathrm{aR}$ in chronic tubulointerstitial diseases, its direct 
renal effect is still unknown. Meanwhile, we cannot confirm the fatal role of the $\mathrm{C} 3 \mathrm{a} / \mathrm{C} 3 \mathrm{aR}$ pathway in the chronic inflammatory fibrosis process because almost all complement and inflammatory factors are involved in this process. It is worth choosing several important factors for comparison.

\section{Urinary Tract Infections}

$\mathrm{C} 3 \mathrm{a} / \mathrm{C} 3 \mathrm{aR}$ exerts a protective effect during infections. For example, in a mouse model of Listeria monocytogenes, C3a/C3aR up-regulated Bcl-2 while down-regulated Fas, caspase- 3, and IFN-B, which ameliorate organism-induced apoptosis $(65,66)$. Similarly, in uropathogenic Escherichia coli (UPEC)-induced renal injury, $\mathrm{C} 3 \mathrm{a} / \mathrm{C} 3 \mathrm{aR}$ also had a protective role by enhancing macrophage phagocytosis induced by LPS despite suppression of inflammatory responses $(67,68)$. Here, C3a agonism may offer an interesting new therapeutic option along with standard antibiotic care.

\section{SUMMARY AND PROSPECTION}

Despite the large number of clinical trials targeting C5, C5a, C5aR1 on AAV, IgAN, aHUS, PNH, and other diseases, and the approved clinical use of eculizumab for $\mathrm{PNH}$, aHUS, and

\section{REFERENCES}

1. Bomback AS, Markowitz GS, Appel GB. Complement-Mediated glomerular diseases: a tale of 3 pathways. Kidney Int Rep. (2016) 1:148-55. doi: 10.1016/j.ekir.2016.06.005

2. Noris M, Remuzzi G. Overview of complement activation and regulation. Semin Nephrol. (2013) 33:479-92. doi: 10.1016/j.semnephrol.2013.08.001

3. Coulthard LG, Woodruff TM. Is the complement activation product C3a a proinflammatory molecule? Re-evaluating the evidence and the myth. $J$ Immunol. (2015) 194:3542-8. doi: 10.4049/jimmunol.1403068

4. Braun MC, Reins RY, Li TB, Hollmann TJ, Dutta R, Rick WA, et al. Renal expression of the $\mathrm{C} 3 \mathrm{a}$ receptor and functional responses of primary human proximal tubular epithelial cells. J Immunol. (2004) 173:41906. doi: 10.4049/jimmunol.173.6.4190

5. Klos A, Wende E, Wareham KJ, Monk PN. International union of basic and clinical pharmacology, LXXXVII, Complement peptide C5a, C4a, and C3a receptors. Pharmacol Rev. (2013) 65:500-43. doi: 10.1124/pr.111.005223

6. He YD, Xu BN, Song D, Wang YQ, Yu F, Chen Q, et al. Normal range of complement components during pregnancy: a prospective study. Am J Reprod Immunol. (2020) 83:e13202. doi: 10.1111/aji.13202

7. Scully CC, Blakeney JS, Singh R, Hoang HN, Abbenante G, Reid RC, et al. Selective hexapeptide agonists and antagonists for human complement C3a receptor. J Med Chem. (2010) 53:4938-48. doi: 10.1021/jm1003705

8. Crass T, Raffetseder U, Martin U, Grove M, Klos A, Köhl J, et al. Expression cloning of the human $\mathrm{C} 3 \mathrm{a}$ anaphylatoxin receptor (C3aR) from differentiated U-937 cells. Eur J Immunol. (1996) 26:1944-50. doi: 10.1002/eji.1830260840

9. Laumonnier Y, Karsten CM, Köhl J. Novel insights into the expression pattern of anaphylatoxin receptors in mice and men. Mol Immunol. (2017) 89:44-58. doi: 10.1016/j.molimm.2017.05.019

10. Litvinchuk A, Wan YW, Swartzlander DB, Chen F, Cole A, Propson NE, et al. Complement $\mathrm{C} 3 \mathrm{aR}$ inactivation attenuates tau pathology and reverses an immune network deregulated in tauopathy models and Alzheimer's disease. Neuron. (2018) 100:1337-53. doi: 10.1016/j.neuron.2018.10.031

11. Gu H, Fisher AJ, Mickler EA, Duerson F, Cummings OW, Peters-Golden $\mathrm{M}$, et al. Contribution of the anaphylatoxin receptors, C3aR and C5aR, to the pathogenesis of pulmonary fibrosis. FASEB J. (2016) 30:233650. doi: 10.1096/fj.201500044 myasthenia gravis, clinical trials targeting C3 are less and mostly on phase I, and no clinical trials targeting C3a or $\mathrm{C} 3 \mathrm{aR}$ are registered. Initial discussions primarily relied on theoretical considerations of primary complement deficiencies, whereas C3 deficiency often leads to a broader range of susceptibilities to infections, which is mostly attributed to the opsonic activity of C3b. However, it can be effectively avoided by developing therapies targeting $\mathrm{C} 3 \mathrm{a} / \mathrm{C} 3 \mathrm{aR}$, which participates in inflammatory responses but not opsonization. The major impediment derives from the controversies over the $\mathrm{C} 3 \mathrm{a} / \mathrm{C} 3 \mathrm{aR}$ functions in different cell types and in different diseases, and the complexity of its intercellular signaling pathways. In-depth investigations and awareness of the roles of $\mathrm{C} 3 \mathrm{a} / \mathrm{C} 3 \mathrm{aR}$ in kidney diseases are needed that will lead to a further expansion of potential indications for complement treatments in the future.

\section{AUTHOR CONTRIBUTIONS}

SG contributed to analysis and manuscript preparation and wrote the manuscript. ZC helped perform the analysis with constructive discussions. MZ contributed to the conception of the study. All authors contributed to the article and approved the submitted version.
12. Guglietta S, Chiavelli A, Zagato E, Krieg C, Gandini S, Ravenda PS, et al. Coagulation induced by C3aR-dependent NETosis drives protumorigenic neutrophils during small intestinal tumorigenesis. Nat Commun. (2016) 7:11037. doi: $10.1038 /$ ncomms 11037

13. Gupta A, Rezvani R, Lapointe M, Poursharifi P, Marceau P, Tiwari $\mathrm{S}$, et al. Downregulation of complement $\mathrm{C} 3$ and $\mathrm{C} 3 \mathrm{aR}$ expression in subcutaneous adipose tissue in obese women. PLoS ONE. (2014) 9:e95478. doi: 10.1371/journal.pone.0095478

14. Mizuno M, Blanchin S, Gasque P, Nishikawa K, Matsuo S. High levels of complement C3a receptor in the glomeruli in lupus nephritis. Am J Kidney Dis. (2007) 49:598-606. doi: 10.1053/j.ajkd.2007.02.271

15. Gao J, Choe H, Bota D, Wright PL, Gerard C, Gerard NP. Sulfation of tyrosine 174 in the human $\mathrm{C} 3 \mathrm{a}$ receptor is essential for binding of C3a anaphylatoxin. J Biol Chem. (2003) 278:37902-8. doi: 10.1074/jbc.M30 6061200

16. Möller T, Nolte C, Burger R, Verkhratsky A, Kettenmann $H$. Mechanisms of $\mathrm{C} 5 \mathrm{a}$ and $\mathrm{C} 3 \mathrm{a}$ complement fragment-induced [Ca2+] i signaling in mouse microglia. J Neurosci. (1997) 17:615-24. doi: 10.1523/JNEUROSCI.17-02-00615.1997

17. Schraufstatter IU, Trieu K, Sikora L, Sriramarao P, DiScipio R. Complement C3a and C5a induce different signal transduction cascades in endothelial cells. J Immunol. (2002) 169:2102-10. doi: 10.4049/jimmunol.169.4.2102

18. Vibhuti A, Gupta K, Subramanian H, Guo Q, Ali H. Distinct and shared roles of b-arrestin-1 and b-arrestin-2 on the regulation of C3a receptor signaling in human mast cells. PLoS ONE. (2011) 6:e19585. doi: 10.1371/journal.pone.0019585

19. Zhou W. The new face of anaphylatoxins in immune regulation. Immunobiology. (2012) 217:225-34. doi: 10.1016/j.imbio.2011.07.016

20. Min X, Liu C, Wei Y, Wang N, Yuan G, Liu D, et al. Expression and regulation of complement receptors by human natural killer cells. Immunobiology. (2014) 219:671-9. doi: 10.1016/j.imbio.2014.03.018

21. Finkelman FD, Khodoun MV, Strait R. Human IgE-independent systemic anaphylaxis. J Allergy Clin Immunol. (2016) 137:167480. doi: 10.1016/j.jaci.2016.02.015

22. Gaudenzio N, Sibilano R, Marichal T, Starkl P, Reber LL, Cenac N, et al. Different activation signals induce distinct mast cell degranulation strategies. J Clin Invest. (2016) 126:3981-98. doi: 10.1172/JCI85538 
23. Asgari E, Le Friec G, Yamamoto H, Perucha E, Sacks SS, Köhl J, et al. C3a modulates IL-1b secretion in human monocytes by regulating ATP efflux and subsequent NLRP3 inflammasome activation. Blood. (2013) 122:347381. doi: 10.1182/blood-2013-05-502229

24. Kwan WH, van der Touw W, Paz-Artal E, Li MO, Heeger PS. Signaling through $\mathrm{C} 5 \mathrm{a}$ receptor and $\mathrm{C} 3$ a receptor diminishes function of murine natural regulatory T cells. J Exp Med. (2013) 210:257-68. doi: 10.1084/jem.20121525

25. Peng Q, Li K, Patel H, Sacks SH, Zhou W. Dendritic cell synthesis of C3 Is required for full $\mathrm{T}$ cell activation and development of a Th1 phenotype. $J$ Immunol. (2006) 176:3330-41. doi: 10.4049/jimmunol.176.6.3330

26. Strainic MG, Liu J, Huang D, An F, Lalli PN, Muqim N, et al. Locally produced complement fragments $\mathrm{C} 5 \mathrm{a}$ and $\mathrm{C} 3 \mathrm{a}$ provide both costimulatory and survival signals to naive CD4+ T cells. Immunity. (2008) 28:42535. doi: 10.1016/j.immuni.2008.02.001

27. Ames RS, Lee D, Foley JJ, Jurewicz AJ, Tornetta MA, Bautsch W, et al. Identification of a selective nonpeptide antagonist of the anaphylatoxin C3a receptor that demonstrateds anti-inflammatory activity in animal models. $J$ Immunol. (2001) 166:6341-8. doi: 10.4049/jimmunol.166.10.6341

28. Mathieu MC, Sawyer N, Greig GM, Hamel M, Kargman S, Ducharme Y, et al. The C3a receptor antagonist SB 290157 has agonist activity. Immunol Lett. (2005) 100:139-45. doi: 10.1016/j.imlet.2005.03.003

29. Woodruff TM, Tenner AJ. A commentary on: "NF B-activated astroglial release of complement C3 compromises neuronal morphology and function associated with Alzheimer's disease". A cautionary note regarding C3aR. Front Immunol. (2015) 6:220. doi: 10.3389/fimmu.2015.00220

30. Humbles AA, Lu B, Nilsson CA, Lilly C, Israel E, Fujiwara Y, et al. A role for the C3a anaphylatoxin receptor in the effector phase of asthma. Nature. (2000) 406:998-1001. doi: 10.1038/35023175

31. Aykut B, Pushalkar S, Chen R, Li Q, Abengozar R, Kim JI, et al. The fungal mycobiome promotes pancreatic oncogenesis via activation of MBL. Nature. (2019) 574:264-7. doi: 10.1038/s41586-019-1608-2

32. Sauter RJ, Sauter M, Reis ES, Emschermann FN, Nording H, Ebenhöch S, et al. Functional relevance of the anaphylatoxin receptor $\mathrm{C} 3 \mathrm{aR}$ for platelet function and arterial thrombus formation marks an intersection point between innate immunity and thrombosis. Circulation. (2018) 138:172035. doi: 10.1161/CIRCULATIONAHA.118.034600

33. Liu G, Wang Q, Shi Y, Peng X, Liu H, Peng Y, et al. Resveratrol attenuates adriamycin-induced focal segmental glomerulosclerosis through C3aR/C5aR- sphingosine kinase 1 pathway. Pharmacology. (2017) 100:25360. doi: 10.1159/000479525

34. Abou-Ragheb HH, Williams AJ, Brown CB, Milford-Ward A. Plasma levels of the anaphylatoxins C3a and C4a in patients with IgA nephropathy/HenochSchönlein nephritis. Nephron. (1992) 62:22-6. doi: 10.1159/000186989

35. Janssen U, Bahlmann F, Köhl J, Zwirner J, Haubitz M, Floege J. Activation of the acute phase response and complement C3 in patients with IgA nephropathy. Am J Kidney Dis. (2000) 35:21-8. doi: 10.1016/S0272-6386(00)70296-4

36. Liu L, Zhang Y, Duan X, Peng Q, Liu Q, Zhou Y, et al. C3a, C5a renal expression and their receptors are correlated to severity of IgA nephropathy. $J$ Clin Immunol. (2014) 34:224-32. doi: 10.1007/s10875-013-9970-6

37. Zhu L, Zhai YL, Wang FM, Hou P, Lv JC, Xu DM, et al. Variants in complement factor $\mathrm{H}$ and complement factor $\mathrm{H}$-related protein genes, CFHR3 and CFHR1, affect complement activation in IgA nephropathy. J Am Soc Nephrol. (2015) 26:1195-204. doi: 10.1681/ASN.2014010096

38. Xie X, Lv J, Shi S, Zhu L, Liu L, Chen M, et al. Plasma exchange as an adjunctive therapy for crescentic IgA nephropathy. Am J Nephrol. (2016) 44:141-9. doi: 10.1159/000448767

39. Zhang $\mathrm{Y}$, Yan $\mathrm{X}$, Zhao $\mathrm{T}, \mathrm{Xu} \mathrm{Q}$, Peng $\mathrm{Q}, \mathrm{Hu} \mathrm{R}$, et al. Targeting $\mathrm{C} 3 \mathrm{a} / \mathrm{C} 5 \mathrm{a}$ receptors inhibits human mesangial cell proliferation and alleviates immunoglobulin A nephropathy in mice. Clin Exp Immunol. (2017) 189:6070. doi: $10.1111 /$ cei.12961

40. Zhang K, Li Q, Zhang Y, Shang W, Wei L, Li H, et al. Clinical significance of galactose-deficient IgA1 by KM55 in patients with IgA nephropathy. Kidney Blood Press Res. (2019) 44:1196-206. doi: 10.1159/000502579

41. Zhang MF, Huang J, Zhang YM, Qu Z, Wang X, Wang F, et al. Complement activation products in the circulation and urine of primary membranous nephropathy. BMC Nephrol. (2019) 20:313. doi: 10.1186/s12882-019-1509-5
42. Yang Y, Wang C, Jin L, He F, Li C, Gao Q, et al. IgG4 antiphospholipase A2 receptor might activate lectin and alternative complement pathway meanwhile in idiopathic membranous nephropathy: an inspiration from a cross-sectional study. Immunol Res. (2016) 64:919-30. doi: 10.1007/s12026-016-8790-1

43. Yang Y, Ma L, Wang C, Kong D, Wang Y, Mei C. Effectiveness of sulodexide might be associated with inhibition of complement system in hepatitis B virusassociated membranous nephropathy: an inspiration from a pilot trial. Eur J Intern Med. (2016) 32:96-104. doi: 10.1016/j.ejim.2016.04.017

44. Morigi M, Locatelli M, Rota C, Buelli S, Corna D, Rizzo P, et al. A previously unrecognized role of $\mathrm{C} 3 \mathrm{a}$ in proteinuric progressive nephropathy. Sci Rep. (2016) 6:28445. doi: 10.1038/srep28445

45. Han R, Hu S, Qin W, Shi J, Hou Q, Wang X. C3a and suPAR drive versican V1 expression in tubular cells of focal segmental glomerulosclerosis. JCI Insight. (2019) 4:122912. doi: 10.1172/jci.insight.122912

46. Han R, Hu S, Qin W, Shi J, Zeng C, Bao H, et al. Upregulated long noncoding RNA LOC105375913 induces tubulointerstitial fibrosis in focal segmental glomerulosclerosis. Sci Rep. (2019) 9:716. doi: 10.1038/s41598-018-36902-2

47. Song D, Guo WY, Wang FM, Li YZ, Song Y, Yu F, et al. Complement alternative pathway's activation in patients with lupus nephritis. Am J Med Sci. (2017) 353:247-57. doi: 10.1016/j.amjms.2017.01.005

48. Bao L, Osawe I, Haas M, Quigg RJ. Signaling through up-Regulated C3a receptor is key to the development of experimental lupus nephritis. J Immunol. (2005) 175:1947-55. doi: 10.4049/jimmunol.175.3.1947

49. Wenderfer SE, Wang H, Ke B, Wetsel RA, Braun MC. C3a receptor deficiency accelerates the onset of renal injury in the MRL/lpr mouse. Mol Immunol. (2009) 46:1397-404. doi: 10.1016/j.molimm.2008.12.004

50. Li XQ, Chang DY, Chen M, Zhao MH. Complement activation in patients with diabetic nephropathy. Diabetes Metab. (2019) 45:24853. doi: 10.1016/j.diabet.2018.04.001

51. Huang H, Li D, Huang X, Wang Y, Wang S, Wang X, et al. Association of complement and inflammatory biomarkers with diabetic nephropathy. Ann Clin Lab Sci. (2019) 49:488-95.

52. Zheng JM, Jiang ZH, Chen DJ, Wang SS, Zhao WJ, Li LJ. Pathological significance of urinary complement activation in diabetic nephropathy: a full view from the development of the disease. J Diabetes Investig. (2019) 10:738-44. doi: 10.1111/jdi.12934

53. Li L, Chen L, Zang J, Tang X, Liu Y, Zhang J, et al. C3a and C5a receptor antagonists ameliorate endothelial-myofibroblast transition via the Wnt/ $\beta$ catenin signaling pathway in diabetic kidney disease. Metabolism. (2015) 64:597-610. doi: 10.1016/j.metabol.2015.01.014

54. Li L, Yin Q, Tang X, Bai L, Zhang J, Gou S, et al. C3a receptor antagonist ameliorates inflammatory and fibrotic signals in type 2 diabetic nephropathy by suppressing the activation of TGF- $\beta / \operatorname{smad} 3$ and IKB $\alpha$ pathway. PLoS ONE. (2014) 9:e113639. doi: 10.1371/journal.pone.0113639

55. Li XQ, Chang DY, Chen M, Zhao MH. Deficiency of C3a receptor attenuates the development of diabetic nephropathy. BMJ Open Diabetes Res Care. (2019) 7:e000817. doi: 10.1136/bmjdrc-2019-000817

56. Danobeitia JS, Djamali A, Fernandez LA. The role of complement in the pathogenesis of renal ischemia-reperfusion injury and fibrosis. Fibrogenesis Tissue Repair. (2014) 7:16. doi: 10.1186/1755-1536-7-16

57. Peng Q, Li K, Smyth LA, Xing G, Wang N, Meader L, et al. C3a and C5a promote renal ischemia-reperfusion injury. J Am Soc Nephrol. (2012) 23:1474-85. doi: 10.1681/ASN.2011111072

58. Thurman JM, Lenderink AM, Royer PA, Coleman KE, Zhou J, Lambris JD, et al. C3a is required for the production of CXC chemokines by tubular epithelial cells after renal ishemia/reperfusion. J Immunol. (2007) 178:181928. doi: 10.4049/jimmunol.178.3.1819

59. Simone S, Rascio F, Castellano G, Divella C, Chieti A, Ditonno P, et al. Complement-dependent NADPH oxidase enzyme activation in renal ischemia/reperfusion injury. Free Radic Biol Med. (2014) 74:26373. doi: 10.1016/j.freeradbiomed.2014.07.003

60. Curci C, Castellano G, Stasi A, Divella C, Loverre A, Gigante $\mathrm{M}$, et al. Endothelial-to-mesenchymal transition and renal fibrosis in ischaemia/reperfusion injury are mediated by complement anaphylatoxins and Akt pathway. Nephrol Dial Transplant. (2014) 29:799-808. doi: 10.1093/ndt/gft516 
61. Liu F, Gou R, Huang J, Fu P, Chen F, Fan WX, et al. Effect of anaphylatoxin C3a, C5a on the tubular epithelial-myofibroblast transdifferentiation in vitro. Chin Med J. (2011) 124:4039-45.

62. Tang Z, Lu B, Hatch E, Sacks SH, Sheerin NS. C3a mediates epithelial-tomesenchymal transition in proteinuric nephropathy. J Am Soc Nephrol. (2009) 20:593-603. doi: 10.1681/ASN.2008040434

63. Bao L, Wang Y, Haas M, Quigg RJ. Distinct roles for C3a and C5a in complement-induced tubulointerstitial injury. Kidney Int. (2011) 80:52434. doi: 10.1038/ki.2011.158

64. Kiafard Z, Tschernig T, Schweyer S, Bley A, Neumann D, Zwirner J. Use of monoclonal antibodies to assess expression of anaphylatoxin receptors in tubular epithelial cells of human, murine and rat kidneys. Immunobiology. (2007) 212:129-39. doi: 10.1016/j.imbio.2006.11.003

65. Mueller-Ortiz SL, Morales JE, Wetsel RA. The receptor for the complement C3a anaphylatoxin (C3aR) provides host protection against Listeria monocytogenes-induce apoptosis. J Immunol. (2014) 193:1278-89. doi: 10.4049/jimmunol.1302787

66. Mueller-Ortiz SL, Calame DG, Shenoi N, Li YD, Wetsel RA. The complement anaphylatoxins C5a and C3a suppress IFN- $\beta$ production in response to Listeria monocytogenes by inhibition of the cyclic dinucleotideactivated cytosolic surveillance pathway. J Immunol. (2017) 198:323744. doi: $10.4049 /$ jimmunol.1601420
67. Hollmann TJ, Mueller-Ortiz SL, Braun MC, Wetsel RA. Disruption of the $\mathrm{C} 5 \mathrm{a}$ receptor gene increases resistance to acute Gram-negative bacteremia and endotoxic shock: opposing roles of $\mathrm{C} 3 \mathrm{a}$ and $\mathrm{C} 5 \mathrm{a}$. Mol Immunol. (2008) 45:1907-15. doi: 10.1016/j.molimm.2007. 10.037

68. Wu KY, Zhang $\mathrm{T}$, Zhao GX, Ma N, Zhao S-J, Wang $\mathrm{N}$, et al. The $\mathrm{C} 3 \mathrm{a} / \mathrm{C} 3 \mathrm{aR}$ axis mediates anti-inflammatory activity and protects against uropathogenic E coli-induced kidney injury in mice. Kidney Int. (2019) 96:612-27. doi: 10.1016/j.kint.2019. 03.005

Conflict of Interest: The authors declare that the research was conducted in the absence of any commercial or financial relationships that could be construed as a potential conflict of interest.

Copyright $\odot 2020 \mathrm{Gao}$, Cui and Zhao. This is an open-access article distributed under the terms of the Creative Commons Attribution License (CC BY). The use, distribution or reproduction in other forums is permitted, provided the original author(s) and the copyright owner(s) are credited and that the original publication in this journal is cited, in accordance with accepted academic practice. No use, distribution or reproduction is permitted which does not comply with these terms. 